Огляди літератури, оригінальні дослідження, погляд на проблему, випадок з практики, короткі повідомлення УДК 618.145-007.415-031.64-036.1-092

DOI 10.11603/1811-2471.2019.v.i3.10494

\title{
СУЧАСНІ ПОГЛЯДИ НА ПАТОГЕНЕЗ ЕКСТРАГЕНІТАЛЬНОГО ЕНДОМЕТРІОЗУ (Огляд літератури)
}

\author{
๑А. М. Барбе, А. М. Бербець, К. М. Барбе, О. М. Юзько
}

Вищий державний навчальний заклад України «Буковинський державний медичний університет»

РЕЗЮмЕ. Ендометріоз - це хронічний доброякісний гормонозалежний стан, при якому за межами слизової оболонки матки відбувається розростання тканини, за морфологічними та функціональними властивостями ідентичної ендометрію. Наведені дані огляду літератури присвячені сучасним поглядам на патогенез екстрагенітального ендометріозу. В статті висвітлені теорії щодо етіології та патогенезу цієї патології, а також описані можливі механізми, які потенційно можна розглядати як ключ до патогенетичної терапії.

Ендометріоз виявляють у 50 \% жінок з дисменореєю, у 50-80\% пацієнток із хронічним тазовим болем та у 25-40 \% жінок із безпліддям, а в структурі гінекологічної захворюваності ендометріоз посідає третє місце після запальних процесів та міоми матки.

Враховуючи не надто високу ефективність лікування та значний відсоток рецидивування захворювання питання актуалізації поглядів на патогенетичні механізми з метою оптимізації лікувальної тактики ендометріозу й досі залишається актуальним.

Мета - провести аналіз літератури з метою виявлення сучасних поглядів щодо патогенезу екстрагеніатльного ендометріозу та можливі точки прикладання при розробці таргетної терапії.

Висновки. Найширше прийнятою теорією патогенезу ендометріозу є теорія ретроградної менструації Семпсона. Ця теорія припускає, що життєздатні фрагменти ендометріальної тканини дисемінуються в перитонеальну порожнину або в органи малого таза. Найімовірнішим еволюціонуванням даної теорії слід вважати теорію ангіогенезу на тлі імунної дисфункції, яка сприяє первинній імплантації ендометріоїдних ектопій та їх подальшому розвитку.

Сучасні дані літератури ставлять на чільне місце в становленні та розвитку уражень роль ангіогенезу, водночас має місце імунна дисфункція, яка, ймовірно, призводить до переважання ангіогенних факторів локально.

КлючОВІ СлОВА: екстрагенітальний ендометріоз; теорії патогенезу; VEGF; MMP; теорія Семпсона; ангіогенез; імунна дисфункція; ретроградна менструація.

Вступ. Ендометріоз - це хронічний доброякісний гормонозалежний стан, при якому за межами слизової оболонки матки відбувається розростання тканини, яка за морфологічними та функціональними властивостями ідентична ендометрію, що призводить до появи клінічних симптомів, які можуть впливати на фізичний стан, психологічний статус і соціальний добробут пацієнтки [1]. Згідно з даними досліджень, ендометріоз діагностують у 5-10 \% жіночої популяції - у світі приблизно 176 млн жінок, переважно репродуктивного віку, з ендометріозом.

Ендометріоз виявляють у 50 \% жінок з дисменореєю, у 50-80 \% пацієнток із хронічним тазовим болем [2] та в 25-40\% жінок із безпліддям, а в структурі гінекологічної захворюваності він обіймає третє місце після запальних процесів та міоми матки [2-4].

Наразі важливе значення у розвитку безпліддя та погіршенні репродуктивного здоров'я жінок належить саме ендометріозу [5], який, за різними даними, наявний у 10-35\% жінок репродуктивного віку $[2,4]$. Враховуючи не надто високу ефективність лікування, значний відсоток рецидивів захворювання після припинення застосування лікарських засобів, а також високий ступінь виникнення побічних дій $[4,6,7]$ внаслідок використання рекомендованих національними протоколами методів лікування питання актуалізації поглядів на патогенетичні механізми та оптимізації лікувальної тактики ендометріозу й досі залишається актуальним.

Мета - провести аналіз літератури з метою виявлення сучасних поглядів на патогенез екстрагенітального ендометріозу та можливі точки прикладання при розробці таргетної терапії.

Результати й обговорення. Сучасні теорії встановлення ендометріоідних уражень. Найширше прийнятою теорією патогенезу ендометріозу $\epsilon$ теорія ретроградної менструації Семпсона. Ця теорія припускає, що життєздатні фрагменти ендометріальної тканини дисемінуються в перитонеальну порожнину або в органи малого таза [8-9]. Теорія Семпсона підтверджується жінками з цервікальним стенозом або іншими конгенітальними обструкціями, які заважають відтоку менструальної крові. Ці жінки мають підвищений ризик розвитку ендометріозу [10-11]. Вказані спостереження були повторені на моделі ендометріозу на павіанах, в яких був індукований цервікальний стеноз [12], ймовірно, через підвищення ступеня ретроградної менструації. Окрім цьо- 
Огляди літератури, оригінальні дослідження, погляд на проблему, випадок з практики, короткі повідомлення

го, було показано, що інтраперитонеальна ін'єкція менструального ендометрія успішно індукує перитонеальний ендометріоз у моделі на павіанах у 3 із 4 павіанів, які були залучені в дослідження, через 12 місяців лапароскопічно було виявлено та підтверджено ендометріоїдні ураження [13].

Теорія целомічної метапалзії постулює, що ендометріоз виникає внаслідок метаплазії клітин, які покривають вісцеральну та парієтальну очеревину, на фоні гормональних, екологічних або інфекційних стимулів. Основа цієї теорії ґрунтується на ембріологічних дослідженнях, які свідчать, що абдомінальна, тазова та торакальна очеревина, Мюллерові протоки та зародковий епітелій яєчника походять із целомічного епітелію ембріона. Оскільки клітинний матеріал, який складає очеревину та ендометрій, має спільне ембріональне походження, яким $\epsilon$ целомічний епітелій, існує вірогідність, що вищезазначені стимули можуть запустити трансформацію клітин очеревини в клітини ендометріального типу. Аналогічно, теорія ембріональних залишків припускає, що ураження розвиваються з клітин, які залишаються після міграції Мюллерових проток протягом ембріонального розвитку внаслідок специфічних стимулів, таких як естрогени, які відіграють вкрай важливу роль у патогенезі ендометріозу [14, 15].

Останнім часом багато уваги приділяють теорії стовбурових клітин. Вважають, що ендометріальні стовбурові клітини / прогеніторні клітини 3 базального шару ендометрія можуть проникнути шляхом ретроградної менструації, лімфатичної або судинної дисемінації в очеревинну порожнину та перерости у вогнища ендометріозу. Гематогенна дисемінація з кісткового мозку стовбурових клітин також може робити внесок у патогенез ендометріозу. В одному експерименті гістеректомізованим LacZ трансгенним мишам з експериментально індукованим перитонеальним ендометріозом згодом було проведено трансплантацію кісткового мозку від LacZ трансгенних мишей. LacZ-експресуючі клітини були виявлені в ектопічному вогнищі, що свідчить про потенціал участі стовбурових клітин кісткового мозку у виникненні та персистуванні захворювання [16].

Підвищена продукція естрадіолу та прогестеронова резистентність при ендометріозі

Як зазначалося раніше, найширше прийнята теорія ретроградної менструації стверджує, що патогенез ендометріозу починається 3 інвазії та проліферації менструальних стоків у перитонеальній рідині. Дослідження показують, що аберантні імунні механізми та реакція на стероїди, що виділяються яєчниками, виявлені тільки у частини жінок, можуть призвести до розвитку ендо- метріоїдних вогнищ у перитонеальній мембрані. Цікаво, що в експериментальній моделі на павіанах ендометрій з менструальної фази, який уводили внутрішньоочеревинно, показав підвищену адгезію до перитонеальної мембрани, порівняно з ендометрієм лютеальної фази [13]. Це говорить про те, що фрагменти ендометрія в менструальній фазі експресують селективні фактори, які ще належить характеризувати, що покращує подальшу імплантацію в аберантних місцях. За нормальних фізіологічних умов ендометрій людини перебуває під циклічною регуляцією естрогенів та прогестерону, з проліферацією, диференціацією та десквамацією поверхневого, функціонального шару ендометрія, якщо імплантація не відбулася. Однак, клітинні компоненти ектопічного вогнища ендометріозу реагують на стероїдні гормони яєчників по-іншому, порівняно з нормальним еутопічним ендометрієм [17, 18]. Макроскопічно видима структурна мальформація ендометріального епітелію у жінок з ендометріозом може бути одним з пояснень збільшення випадків неплідності у жінок з ендометріозом [19] і, можливо, пояснює, чому ендометріоз розвивається тільки у частини жінок.

Естрадіол (Е2), біологічно активна форма естрогену, відіграє важливу роль у процесі відновлення ендометрія після менструації. Проліферація ендометріоїдних клітин і відновлення судинної мережі функціонального шару ендометрія керується впливом E2, взаємодіючи із ядерними рецепторами, ER-a та ER- $\beta$. Ендометріальний E2 утворюється переважно в яєчниках, а також у позаоваріальних тканинах, таких як надниркові залози та адипоцити, які надходять у тканини через кровообіг. Ароматаза Р450 є ферментом, який каталізує перетворення оваріального андростендіону в естрон. 17ß-гідроксистероїддегідрогеназа типу 1 (17ß-HSDT1) в подальшому каталізує перетворення естрону в Е2. Простагландин Е2 (ПГЕ2) синтезується з арахідонової кислоти залежно від активності лімітуючого ферменту циклооксигенази-2 (ЦОГ-2) [17]. ПГЕ2 індукує продукування ароматази Р450 через цАМФ каскад клітинної сигналізації в ектопічних ендометріальних стромальних клітин дозозалежним чином [20]. В ендометрії здорових жінок активність ароматази P450 не визначається [20]. Однак, як ендометрій, так і ендометріоїдні ураження у жінок з ендометріозом, експресують цей фермент у значно більшій кількості, сприяючи таким чином місцевому утворенню Е2. Здатність ендометріоїдного ураження виробляти E2 de novo, поряд із продукуванням ферментів, необхідних для цього, може сприяти імплантації фрагментів ендометрія у черевну порожнину $[20,21]$. 
Огляди літератури, оригінальні дослідження, погляд на проблему, випадок з практики, короткі повідомлення

Зважаючи на значну роль Е2 у патогенезі ендометріозу, існують різні фармацевтичні заходи, спрямовані на пригнічення утворення естрогенів, проте зі змінним успіхом. Найчастіше симптоми болю можуть бути усунені під час лікування, однак з припиненням лікування біль часто з'являється негайно. Більше половини хворих, які використовували прогестини, повідомили про рецидив тазового болю після припинення лікування [22]. Додатково до посиленої локальної продукції Е2 в ендометрії, як еутопічному, так і ектопічному, у жінок з ендометріозом, резистентність до прогестерону робить свій внесок у патогенез ендометріозу. Прогестерон, який виробляється в основному під час секреторної фази менструального циклу, гальмує дію естрогену і готує ендометрій до імплантації. Процесу децидуалізації, під час якого ендометріальні клітини починають диференціюватися, сприяє прогестерон. Як і естроген, прогестерон взаємодіє із двома рецепторними ізоформами PR-A та PR-B, кожна з яких має різні функції. Генна абляція PR-A у мишей призводить до аномалій матки та яєчників, тоді як абляція гена PR-B не впливає на функцію цих органів [23]. Крім того, транскрипція як PR-A, так і PR-B, виконується з одного гену, з коротшою транскрипцією для PR-A та довшою для PR-B, що приводить до здатності PR-A стати трансрепресором для PR-B та інших ядерних рецепторів [23]. Цікаво, що вогнищам ендометріозу бракує PR-B та трансрепресор PR-A ледь виражений [24]. Це є свідченням того, що прогестеронова резистентність при ендометріозі має місце на молекулярному рівні. Знижену реакцію на прогестерон вивчали Bulun та ін. [25], вони виявили зниження чутливості ендометріоїдних стромальних клітин до прогестерону шляхом вимірювання рівнів МРНК пролактину, який зазвичай індукується прогестероном. Лікування ендометріоїдних стромальних клітин медроксипрогестероном ацетату (МПА), синтетичним аналогом прогестерону, привело до значно нижчого рівня МРНК пролактину, порівняно з еутопічними ендометріальними стромальними клітинами [25]. Така стійкість до прогестеронового лікування забезпечує підвищення локальної концентрації Е2 через нездатність прогестерону до активації 17ß-гідроксистероїддегідрогенази типу 2 (17ß-HSDT2), яка каталізує деактивацію E2 у естрон [26]. Як правило, прогестероноопосередковані фактори ендометріальних стромальних клітин індукують експресію $17 \beta$-гідроксистероїддегідрогенази типу 2 з ендометріальних епітеліальних клітин в паракриновій манері. Цей механізм був пригнічений у лінії ендометріальних епітеліальних клітин Ishikawa, які культивувалися з умовним середовищем від ектопічних ендометріоїдних стромальних клітин $[26,27]$.
Ангіогенез та васкулогенез при ендометріозі

Фрагменти ендометрія, які відділяються від ендометрія матки, можуть бути носіями ангіогенного потенціалу завдяки наступним характеристикам. Ендометрій людини, який складається з функціонального та базального шару - це унікальний орган, який зазнає проліферації, диференціювання й регенерації при кожному менструальному циклі, під регуляцією стероїдних гормонів яєчників - естрогенів та прогестерону. Поряд із ростом ендометрія, його судинне русло зазнає проліферації та регенерації під час кожного циклу під впливом стероїдів яєчників, особливо Е2. Shifren та співавт. [28] визначили підвищену експресію мРНК вазального ендотеаліального фактора росту судин (VEGF) у функціональному шарі ендометрія в проліферативній та секреторній фазах менструального циклу, що вказує на причетність ангіогенезу [29]. VEGF має мітогенний вплив на ендотеліальні клітини. In vitro він сприяє проліферації, міграції та формуванню трубки з ендотеліальних клітин [30]. У різноманітних in vivo моделях він індукує сильну ангіогенну відповідь [31]. Вважають, що VEGF індукує ангіогенез шляхом залучення VEGF-рецептора типу 2 (VEGFR-2 a6о KDR чи F(k-1), що призводить до його фосфорилювання, та ряд низхідних сигнальних подій $[32,33]$. Виявлено, що Е2 відповідає за стимуляцію експресії VEGF у ізольованих людських клітинах ендометрія, а застосування Е2 призводило до збільшення експресії MPHK VEGF, порівняно із ендометріальними клітинами без стимулу E2 [32, 34].

Справді, VEGF відіграє важливу роль у сприянні процесу ангіогенезу при ендометріозі. Це вазоактивна речовина, яка бере участь у різних нормальних фізіологічних процесах, включаючи загоєння ран і реваскуляризацію ендометрія, $\epsilon$ посередником у проліферації ендотелію та міграції. При туморогенезі концентрація VEGF зазвичай корелює із посиленням кровопостачання в різних видах тканин, які асоційовані із пухлиною [35]. Підвищений рівень концентрації VEGF у перитонеальній рідині та плазмі крові у жінок з ендометріозом позитивно асоціюється із підвищеною проліферативною активністю та щільністю мікросудин у вогнищі ендометріозу [36], що вказує на його участь у розвитку судин $[37,38]$. Lin та співавт. [39] з'ясували значимість імунних клітин, продемонструвавши, що ангіогенез у ендометріоїдних ураженнях відбувається після проникнення нейтрофілів та макрофагів, які секретують VEGF, в ураження, а також в черевну порожнину, що вказує на істотну роль інфільтрації лейкоцитів у мишачій моделі ендометріозу. Постнатальну неоваскуляризацію раніше вважали можливою лише в обмежених випадках. Тепер очевидно, що при 
Огляди літератури, оригінальні дослідження, погляд на проблему, випадок з практики, короткі повідомлення

васкуляризації ендометріозу в місці ураження відбуваються як ангіогенез, так і васкулогенез. Під регуляцією E2, який збільшує експресію VEGF перитонеальних макрофагів, неоваскуляризація ендометріоїдних уражень, схоже, відбувається в основному з раніше існуючих судин перитонеальної мембрани в процесі ангіогенезу. Повне з'ясування механізмів, що лежать в основі процесу ангіогенезу, залишається складним через інші імунні клітини та медіатори, які беруть участь у неоваскуляризації.

\section{Імунна дисфункція при ендометріозі}

У жінок репродуктивного віку частота ендометріозу $\epsilon$ невеликою, порівняно із частотою виникнення ретроградної менструації, яку мають більшість жінок з тієї ж категорії. Гіпотеза, яка з цього випливає, вказує на те, що жінки, у яких розвивається ендометріоз, порівняно з тими, у яких не розвивається, мають дефектну імунну систему, яка нездатна розпізнавати та вірно сформувати імунну відповідь щодо ендометріальних фрагментів, які потрапляють в очеревинну порожнину.

Менструальні фрагменти ендометрія викликають запальну реакцію в очеревинній порожнині [40]. У відповідь на присутність цих фрагментів, «сторожі» імунної системи, такі як нейтрофіли та макрофаги, є одними з перших, які ідентифікуються в даній ділянці. Лінії мишей, збіднені на ма- крофаги Balb/C, показали експериментально викликані вогнища ендометріозу, які не тільки мають меншу вагу та розмір, порівняно із контролем (лінія звичайних мишей), а й меншу васкуляризацію [41], що вказує на те, що макрофаги беруть участь у процесі росту і розвитку кровоносних судин $[42,43]$.

Висновки. Сучасні уявлення щодо механізмів розвитку та патогенезу ендометріозу на чільне місце в становленні та розвитку уражень ставлять роль ангіогенезу, водночас має місце імунна дисфункція, яка, ймовірно, призводить до переважання ангіогенних факторів локально в місцях імплантації фрагментів еутопічного ендометрія, а також сприяє VEGF-опосередкованому ангіогенезу.

Визначено, що існують й інші, альтернативні шляхи активації ангіогенезу, як-от ЦОГ-2/ПГЕ2. За даними деяких джерел, між VEGF-опосередкованим механізмом та ЦОГ-2/ПГЕ2 механізмом існує взаємна кросс-регуляція.

Перспективи подальших досліджень. 3 огляду на провідну роль факторів агресії при імплантації ендометріальних фрагментів до очеревини та факторів ангіогенезу для росту судин і капілярів для подальшого розвитку даних ектопій, виглядає перспективним пошук лікарських речовин, які здатні зменшити дію вищеперерахованих факторів, з метою терапії ранніх стадій зовнішнього генітального ендометріозу.

\section{ЛІТЕРАТУРА}

1. Guidice L. C. Endometriosis / L. C. Guidice // Lancet. - 2010. - Vol. 362. - P. 2389-2398.

2. Leyland N. Endometriosis: diagnosis and management, SOGC Clinical and practical guideline / N. Leyland, R. Casper, P. Laberge, S. S. Singh. - 2010. - Vol. 7, No. 32. - P. 1-28.

3. ESHRE guideline [Electronic resource] // ESHRE. 2018. - Access mode : https://www.eshre.eu/Guidelinesand-Legal/Guidelines/Endometriosis-guideline.aspx.

4. Missmer S. A. Incidence of laparoscopically confirmed endometriosis by demographic, anthropometric, and lifestyle factors / S. A. Missmer, S. E. Hankonson, D. Spiegelman [et al.]. - 2004. - No. 160. - P. 784-96.

5. Endometriosis: Does It Cause Infertility? [Electronic resource]. - 2012. - Access mode : http://www.socrei.org/ uploadedFiles/ASRM_Content/Resources/Patient_Resources/Fact_Sheets_and_Info_Booklets/EndoDoesltCauselnfertility.pdf.

6. ESHRE guideline for the diagnosis and treatment of endometriosis / S. Kennedy, A. Bergqvist, C. Chapron [et al.] // Human Reproduction. - 2005. - Vol. 20, No. 10. P. 2698-2704.

7. Cheong Y. C. Non-surgical interventions for the management of chronic pelvic pain / Y. C. Cheong, G. Smot-

ra, A. C. Williams // Cochrane Database Systematic Review. -2014. - Vol. 3.

8. Kettel W. C. The viability of the cast-off menstrual endometrium / W. C. Kettel, R. J. Stein // American Journal of Obstetrics \& Gynecology. - 1951. - Vol. 61, No. 2. P. 440-442.

9. Sampson J. A. Peritoneal endometriosis due to the menstrual dissemination of endometrial tissue into the peritoneal cavity / J. A. Sampson // American Journal of Obstetrics \& Gynecology. - 1927. - Vol. 14. - P. 422-469.

10. Barbieri R. L. Stenosis of the external cervical os: an association with endometriosis in women with chronic pelvic pain / R. L. Barbieri // Fertility and Sterility. - 1998. Vol. 70, No. 3. - P. 571-573.

11. Sanfilipo J. S. Endometriosis in association with uterine anomaly / J. S. Sanfilipo, N. G. Wakim, Schikler [et al.]// American Journal of Obsterics \& Gynecology. -1996.Vol. 154, No. 1. - P. 39-43.

12. Development of a model of retrograde menstruation in baboons (Papio anubis) / T. M. D'Hooghe, C. S. Bambra, M. A. Suleman [et al.] // Fertility and Sterility. - 1994. Vol. 62, No. 3. - P. 635-638.

13. Intrapelvic injection of menstrual endometrium causes endometriosis in baboons (Papio cynocephalus and 
Огляди літератури, оригінальні дослідження, погляд на проблему, випадок з практики, короткі повідомлення

Papio anubis) / T. M. D'Hooghe, C. S. Bambra, B. M. Raeymaekers [et al.] // American Journal of Obstetrics \& Gynecology. - 1995. - Vol. 173, No. 1. - P. 125-134.

14. Burney R. O. Pathogenesis and pathophysiology of endometriosis / R. O. Burney, L. C. Guidice // Fertility and Sterility. - 2012. - Vol. 98, No. 3. - P. 511-519.

15. Tosti. Pathogenetic mechanisms of deep infiltrating endometriosis / Tosti, S. Pinzauti, P. Santulli [et al.] // Reproductive Sciences. - 2015. - Vol. 22, No. 9. P. 1053-1059.

16. Du H. Contribution of bone marrow-derived stem cells to endometrium and endometriosis / H. Du, H. S. Taylor // Stem Cells. - 2007. - Vol. 25, No. 8. - P. 2082-2086.

17. Bulun S. E. Endometriosis / S. E. Bulun // The New England Journal of Medicine. - 2009. - Vol. 360. P. 268-279.

18. Dai Q. A truncated progesterone receptor (PR-M) localizes to the mitochondrion and controls cellular respiration / Q. Dai, A. A. Shah, R. V. Garde // Molecular Endocrinology. - 2014. - Vol. 27, No. 5. - P. 741-753.

19. Sharpe-Timms K. L. Endometrial anomalies in women with endometriosis. / K. L. Sharpe-Timms // Annals of the New York Academy of Sciences. - 2001. - Vol. 943. P. 131-147.

20. Singh A. K. Altered circulating levels of matrix metalloproteinases 2 and 9 and their inhibitors and effect of progesterone supplementation in women with endometriosis undergoing in vitro fertilization / A. K. Singh, B. Chakravarty, R. Charropadhyay // Fertility and Sterility. 2014. - Vol. 100, No. 1. - P. 127-134.

21. Attar E. Aromatase and other steroidogenic genes in endometriosis: Translational aspects / E. Attar, S. E. Bulun // Human Reproduction Update. - 2006. - Vol. 12, No. 1. - P. 49-56.

22. Androgens upregulate endometrial epithelial progesterone receptor expression: Potential implications for endometriosis / S. N. Babayev, C. W. Park, P. W. Keller [et al.] // Reproductive Sciences. - 2017. - Vol. 24, No. 10. P. 1454-1461.

23. Li X. Unfolding the action of progesterone receptors / X. Li, B. W. O`Malley // The Journal of Biological Chemistry. - 2003. - Vol. 278, No. 41. - P. 39261-39264.

24. New horizons in the etiopathogenesis and non-invasive diagnosis of endometriosis / A. Zubrzycka, M. Zubrzycki, A. Janecka, M. Zubrzycka // Current Molecular Medicine. - 2015. - Vol. 15, No. 8. - P. 697-713.

25. Bulun S. E. Progesterone resistance in endometriosis: link to failure to metabolize estradiol / S. E. Bulun, Y. H. Cheng, P. Yin // Molecular and Cellular Endocrinology.2006. - Vol. 248, No. 1-2. - P. 94-103.

26. Investigation of diagnostic potentials of nine different biomarkers in endometriosis / E. Ozhan, A. Kokcu, K. Yanik, M. Gunaydin // European Journal of Obstetrics \& Gynecology. - 2014. - Vol. 178. - P. 128-133.

27. The miRNA mirage: How close are we to finding a non-invasive diagnostic biomarker in endometriosis? A systematic review / S. Agrawal, T. Tapmeier, N. Rahmioglu [et al.] // Inernational Journal of Molecular Sciences. - 2018. Vol. 19, No. 2. - P. 599-605.

28. Shifren J. L. Ovarian steroid regulation of vascular endothelial growth factor in the human endometrium: implications for angiogenesis during the menstrual cycle and in the pathogenesis of endometriosis / J. L. Shifren, J. F. Tseng, C. J. Zaloudek // The Journal of Clinical Endocrinology and Metabolism. - 1996. - Vol. 81, No. 8. P. 3112-3118.

29. Reis F. M. Endometriosis: hormone regulation and clinical consequences of chemotaxis and apoptosis / F. M. Reis, F. Petraglia, R. N. Taylor // Human Reprod Update. - 2013. - Vol. 19, No. 4. - P. 406-418.

30. Mohamed M. L. Comparative study between VEGF-A and CA-125 in diagnosis and follow-up of advanced endometriosis after conservative laparoscopic surgery / M. L. Mohamed, M. M. El Behery, S. A. Mansour // Archives of Gynecology and Obstetrics. - 2013. - Vol. 287, No. 1. P. 77-82.

31. Kianpour M. Serum and peritoneal fluid levels of vascular endothelial growth factor in women with endometriosis / M. Kianpour, M. Nematbakhsh, S. M. Ahmadi // International Journal of Fertility and Sterility. - 2015. Vol. 7, No. 2. - P. 96-99.

32. Ferrara N. Vascular endothelial growth factor: molecular and biological aspects / N. Ferrara // Curent Topics of Microbiology and Immunology. - 1999. - Vol. 237. - P. 1-30.

33. Blocking of stromal cell-derived factor- 1 reduces neoangiogenesis in human endometriosis lesions in a mouse model / S. Virani, A. K. Edwards, R. Thomas [et al.] // American Journal of Reproductive Immunology. - 2013. Vol. 70, No. 5. - P. 386-397.

34. Hyun Ahn S. Biomarkers in endometriosis: challenges and opportunities / S. Hyun Ahn, V. Singh, Tayade // Fertility and Sterility. - 2017. - Vol. 107, No. 3. - P. 523-532.

35. Vascular endothelial growth factor and angiogenesis / A. Hoeben, B. Landuyt, M. S. Highley [et al.] // Pharmacological Reviews. - 2004. - Vol. 56, No. 4. - P. 549-580.

36. Update on biomarkers for the detection of endometriosis / A. Fassbender, R. Burney, F.O. Dorien [et al.] // BioMed Research International. - 2015. - Vol. 15. P. 501-515.

37. Sahin M. Cyclooxygenase-2 in cancer and angiogenesis. / M. Sahin, E. Sahin, S. Gumuslu // Angiology. 2009. - Vol. 60. - P. 242-253.

38. Postnatal vasculogenesis / D. Ribatti, A. Vacca, B. Nico [et al.] // Mechanisms of Development. - 2001. Vol. 100, No. 2. - P. 157-163.

39. Neutrophils and macrophages promote angiogenesis in the early stage of endometriosis in a mouse model / Y. J. Lin, M. D. Lai, H. Y. Lei, L.Y. Wing // Endocrinology. 2006. - Vol. 147, No. 3. - P. 1278-1286.

40. Chen G. Y. Sterile inflammation: sensing and reacting to damage / G. Y. Chen, G. Nunez // Nature Reviews Immunlogy. - 2010. - Vol. 10. - P. 826-837.

41. Bacci M. Macrophages are alternatively activated in patients with endometriosis and required for growth and vascularization of lesions in a mouse model of disease / M. Bacci, A. Capobianco, A. Monno // American Journal of Pathology. - 2009. - Vol. 175, No. 2. - P. 547-556.

42. Králíčková M. Immunological aspects of endometriosis: a review / M. Králíčková, Vetvicka // Annals of Translational Medicine. - 2015. - Vol. 3, No. 11. - P. 153-160.

43. Riccio D. G. Immunology of endometriosis / D. G. Riccio, Santulli, Abrão, Marcellin, Batteux // Best Practice \& Research Clinical Obstetrics \& Gynaecology. 2018. - Vol. 50. - P. 39-49. 
Огляди літератури, оригінальні дослідження, погляд на проблему, випадок з практики, короткі повідомлення REFERENCES

1. Guidice, L.C. (2010). Endometriosis. Lancet, 362, 2389-2398.

2. Leyland, N., Casper, R., Laberge, P., \& Singh, S.S. (2010). Endometriosis: diagnosis and management, SOGC Clinical and practical guideline. 7 (32), 1-28.

3. ESHRE. (2018). ESHRE guideline. (ESHRE) Retrieved, from: https://www.eshre.eu/Guidelines-and-Legal/Guidelines/Endometriosis-guideline.aspx

4. Missmer, S.A., Hankonson, S.E., Spiegelman, D., Barbieri, R. L., Marshall, L. M., \& Hunter, D.J. (2004). Incidence of laparoscopically confirmed endometriosis by demographic, anthropometric, and lifestyle factors. (160), 78496.

5. Endometriosis: Does It Cause Infertility? (2012). Retrieved from American Society or Reproductive Medicine: http://www.socrei.org/uploadedFiles/ASRM_Content/Resources/Patient_Resources/Fact_Sheets_and_ Info_Booklets/EndoDoesitCauselnfertility.pdf

6. Kennedy, S., Bergqvist, A., Chapron, C., D'Hooghe, T., \& Dunselman, G. (2005). ESHRE guideline for the diagnosis and treatment of endometriosis. Human Reproduction, 20 (10), 2698-2704.

7. Cheong, Y.C., Smotra, G., \& Williams, A.C. (2014). Non-surgical interventions for the management of chronic pelvic pain. Cochrane Database Systematic Review, 3.

8. Kettel, W.C., \& Stein, R.J. (1951). The viability of the cast-off menstrual endometrium. American Journal of Obstetrics \& Gynecology, 61 (2), 440-442.

9. Sampson, J. A. (1927). Peritoneal endometriosis due to the menstrual dissemination of endometrial tissue into the peritoneal cavity. American Journal of Obstetrics \& Gynecology, 14, 422-469.

10. Barbieri Bacci, R.L. (1998). Stenosis of the external cervical os: an association with endometriosis in women with chronic pelvic pain. Fertility and Sterility, 70 (3), 571-573.

11. Sanfilipo, J.S., Wakim, N.G., Schikler, K.N., \& Yussman, M.A. (1996). Endometriosis in association with uterine anomaly. American Journal of Obsterics \& Gynecology, $154(1), 39-43$.

12. D'Hooghe, T.M., Bambra, C.S., Suleman, M.A., Dunselman, G.A., \& Evers, H.L. (1994). Development of a model of retrograde menstruation in baboons (Papio anubis). Fertility and Sterility, 62 (3), 635-638.

13. D'Hooghe, T.M., Bambra, C.S., Raeymaekers, B.M., de Jonge, I., \& Lauweryns, J.M. (1995). Intrapelvic injection of menstrual endometrium causes endometriosis in baboons (Papio cynocephalus and Papio anubis). American Journal of Obstetrics \& Gynecology, 173 (1), 125-134.

14. Burney, R.O., \& Guidice, L.C. (2012). Pathogenesis and pathophysiology of endometriosis. Fertility and Sterility, 98 (3), 511-519.

15. Tosti, C., Pinzauti, S., Santulli, P., Chapron, C., \& Petraglia, F. (2015). Pathogenetic mechanisms of deep infiltrating endometriosis. Reproductive Sciences, 22 (9), 10531059.

16. Du, H., \& Taylor, H. S. (2007). Contribution of bone marrow-derived stem cells to endometrium and endometriosis. Stem Cells, 25 (8), 2082-2086.

17. Bulun, S.E. (2009). Endometriosis. The New England Journal of Medicine, 360, 268-279.

18. Dai, Q., Shah, A.A., \& Garde, R.V. (2014). A truncated progesterone receptor (PR-M) localizes to the mitochondrion and controls cellular respiration. Molecular Endocrinology, $27(5), 741-753$.

19. Sharpe-Timms, K.L. (2001). Endometrial anomalies in women with endometriosis. Annals of the New York Academy of Sciences, 943, 131-147.

20. Singh, A.K., Chakravarty, B., \& Charropadhyay, R. (2014). Altered circulating levels of matrix metalloproteinases 2 and 9 and their inhibitors and effect of progesterone supplementation in women with endometriosis undergoing in vitro fertilization. Fertility and Sterility, 100 (1), 127-134.

21. Attar, E., \& Bulun, S. E. (2006). Aromatase and other steroidogenic genes in endometriosis: Translational aspects. Human Reproduction Update, 12 (1), 49-56.

22. Babayev, S.N., Park, C.W., Keller, P.W., Carr, B.R., \& Word, R.A. (2017). Androgens upregulate endometrial epithelial progesterone receptor expression: potential implications for endometriosis. Reproductive Sciences, 24 (10), 1454-1461.

23. Li, X., \& O`Malley, B.W. (2003). Unfolding the action of progesterone receptors. The Journal of Biological Chemistry, 278 (41), 39261-39264.

24. Zubrzycka A., Zubrzycki M., Janecka A., Zubrzycka M. (2015). New horizons in the etiopathogenesis and non-invasive diagnosis of endometriosis. Current Molecular Medicine, 15 (8), 697-713.

25. Bulun, S.E., Cheng, Y.H., \& Yin, P. (2006). Progesterone resistance in endometriosis: link to failure to metabolize estradiol. Molecular and Cellular Endocrinology, 248 (1-2), 94-103.

26. Ozhan, E., Kokcu, A., Yanik, K., \& Gunaydin, M. (2014). Investigation of diagnostic potentials of nine different biomarkers in endometriosis. European Journal of Obstetrics \& Gynecology, 178, 128-133.

27. Agrawal, S., Tapmeier, T., Rahmioglu, N., Kirtley, S., \& Zondervan, K.T. (2018). The miRNA mirage: how close are we to finding a non-invasive diagnostic biomarker in endometriosis? a systematic review. Inernational Journal of Molecular Sciences, 19 (2), 599-605.

28. Shifren, J.L., Tseng, J.F., \& Zaloudek, C.J. (1996). Ovarian steroid regulation of vascular endothelial growth factor in the human endometrium: implications for angiogenesis during the menstrual cycle and in the pathogenesis of endometriosis. The Journal of Clinical Endocrinology and Metabolism, 81 (8), 3112-3118.

29. Reis, F.M., Petraglia, F., \& Taylor, R.N. (2013). Endometriosis: hormone regulation and clinical consequences of chemotaxis and apoptosis. Human Reprod Update, 19 (4), 406-418.

30. Mohamed, M.L., El Behery, M.M., \& Mansour S.A. (2013). Comparative study between VEGF-A and CA-125 in diagnosis and follow-up of advanced endometriosis after conservative laparoscopic surgery. Archives of Gynecology and Obstetrics, 287 (1), 77-82.

31. Kianpour, M., Nematbakhsh, M., \& Ahmadi, S.M. (2015). Serum and peritoneal fluid levels of vascular endothelial growth factor in women with endometriosis. International Journal of Fertility and Sterility, 7(2), 96-99.

32. Ferrara, N. (1999). Vascular endothelial growth fac- 
Огляди літератури, оригінальні дослідження, погляд на проблему, випадок з практики, короткі повідомлення

tor: molecular and biological aspects. Curent Topics of Microbiology and Immunology, 237, 1-30.

33. Virani, S., Edwards, A. K., Thomas, R., Childs, T., \& Tayade, C. (2013). Blocking of stromal cell-derived factor- 1 reduces neoangiogenesis in human endometriosis lesions in a mouse model. American Journal of Reproductive Immunology, 70 (5), 386-397.

34. Hyun Ahn, S., Singh, V., \& Tayade, C. (2017). Biomarkers in endometriosis: challenges and opportunities. Fertility and Sterility, 107 (3), 523-532.

35. Hoeben, A., Landuyt, B., Highley, M.S., Wildiers, H., van Oosterom, A. T., \& de Bruijn, E. A. (2004). Vascular endothelial growth factor and angiogenesis. Pharmacological Reviews, 56 (4), 549-580.

36. Fassbender, A., Burney, R.O., Dorien, F.O., D'Hooghe, T., \& Giudice, L. (2015). Update on biomarkers for the detection of endometriosis. BioMed Research International, 15, 501-515.

37. Sahin, M., Sahin, E., \& Gumuslu, S. (2009). Cyclooxygenase-2 in cancer and angiogenesis. Angiology, 60, 242253.
38. Ribatti, D., Vacca, A., Nico, B., Roncali, L., \& Dammanacco, F. (2001). Postnatal vasculogenesis. Mechanisms of Development, 100 (2), 157-163.

39. Lin, Y.J., Lai, M.D., Lei, H.Y., \& Wing, L.Y. (2006). Neutrophils and macrophages promote angiogenesis in the early stage of endometriosis in a mouse model. Endocrinology, 147 (3), 1278-1286.

40. Chen, G.Y., \& Nunez, G. (2010). Sterile inflammation: sensing and reacting to damage. Nature Reviews Immunlogy, 10, 826-837.

41. Bacci, M., Capobianco, A., \& Monno, A. (2009). Macrophages are alternatively activated in patients with endometriosis and required for growth and vascularization of lesions in a mouse model of disease. American Journal of Pathology, 175 (2), 547-556.

42. Králíčková, M., \& Vetvicka, V. (2015). Immunological aspects of endometriosis: a review. Annals of Translational Medicine, 3(11), 153-160.

43. Riccio, L.D., Santulli, P., Abrão, M.S., Marcellin, L., \& Batteux, F. (2018). Immunology of endometriosis. Best Practice \& Research Clinical Obstetrics \& Gynaecology, 50, 39-49.

\title{
СОВРЕМЕННЫЕ ВЗГЛЯДЫ НА ПАТОГЕНЕЗ ЭКСТРАГЕНИТАЛЬНОГО ЭНДОМЕТРИОЗА (Обзор литературы)
}

\author{
๑А. М. Барбэ, А. Н. Бербец, К. М. Барбэ, А. М. Юзько
}

Высшее государственное учебное заведение Украины «Буковинский государственный медицинский университет»

РЕЗЮМЕ. Эндометриоз - это хроническое доброкачественное гормонозависимое состояние, при котором за пределами слизистой оболочки матки происходит разрастание ткани, по морфологическим и функциональным свойствам идентичной эндометрию. Приведены данные обзора литературы, посвященные современным взглядам относительно патогенеза экстрагенитального эндометриоза. В статье приведены как теории этиологии и патогенеза данной патологии, так и возможные механизмы, которые могут рассматриваться как ключ к патогенетической терапии.

Эндометриоз обнаруживают у 50 \% женщин с дисменореей, у 50-80\% пациенток с хронической тазовой болью и у 25-40 \% женщин с бесплодием, а в структуре гинекологической заболеваемости эндометриоз занимает третье место после воспалительных процессов и миомы матки. Учитывая не слишком высокую эффективность лечения, значительный процент рецидивов заболевания вопрос актуализации взглядов на патогенетические механизмы с целью оптимизации лечебной тактики эндометриоза до сих пор остается актуальным.

Цель - провести анализ литературы с целью выявления современных взглядов относительно патогенеза екстрагениатльного эндометриоза и возможных точек приложения при разработке таргетной терапии.

Выводы. Наиболее широко принятой теорией патогенеза эндометриоза является теория ретроградной менструации Сэмпсона. Данная теория предполагает, что жизнеспособные фрагменты эндометрия ткани дисеминируються в перитонеальную полость или в органы малого таза. Наиболее вероятным эволюционированием данной теории следует считать теорию ангиогенеза на фоне иммунной дисфункции, которая способствует первичной имплантации эндометриоидных эктопий и их дальнейшему развитию.

Современные данные литературы ставят во главу угла роль ангиогенеза в становлении и развитии поражений, в то же время имеет место иммунная дисфункция, которая, вероятно, приводит к преобладанию ангиогенных факторов локально.

КЛЮЧЕВЫЕ СЛОВА: экстрагенитальный эндометриоз; теории патогенеза; VEGF; MMP; теория Сэмпсона; ангиогенез; иммунная дисфункция; ретроградная менструация. 
Огляди літератури, оригінальні дослідження, погляд на проблему, випадок з практики, короткі повідомлення

\section{MODERN VIEWS ON THE PATHOGENESIS OF EXTRAGENITAL ENDOMETRIOSIS (Literature review)}

\section{@A. M. Barbe, A. M. Berbets, K. M. Barbe, O. M. Yuzko}

\section{Bukovinian State Medical University}

SUMMARY. Endometriosis is a chronic benign hormone-dependent condition in which endometrium spreads and grows outside the uterine mucosa, with identical to eutopic endometrium morphological and functional properties. This review is dedicated to modern view on pathogenesis of extragenital endometriosis. The article presents both the theory of etiology and pathogenesis of this pathology and possible mechanisms that can potentially be considered as the key to pathogenetic therapy.

Endometriosis is detected in $50 \%$ of women with dysmenorrhea, in 50-80\% of patients with chronic pelvic pain and in 25-40\% of women with infertility, and in the structure of gynecological disease, endometriosis ranks third after inflammatory processes and uterine fibroids. Considering the not-too-high effectiveness of treatment, a significant percentage of recurrence of the disease, the issue of updating views on pathogenetic mechanisms in order to optimize the therapeutic endometriosis tactic still remains relevant.

The aim - to conduct the literature analysis in order to identify contemporary views on the pathogenesis of extragenital endometriosis and possible points of application in the development of targeted therapy.

Conclusions. The most widely accepted theory of pathogenesis of endometriosis is the theory of retrospective menstruation of Sampson. This theory suggests that viable fragments of the endometrial tissue disintegrate into the peritoneal cavity or into the pelvic organs. The most probable evolution of this theory should be the theory of angiogenesis on the background of immune dysfunction, which contributes to the primary implantation of endometrioid ectopic and their subsequent development.

Modern literature points to the role of angiogenesis in the formation and development of lesions, but at the same time, there is an immune dysfunction, which probably leads to the predominance of angiogenic factors locally.

KEY WORDS: extragenital endometriosis; pathogenesis theory; VEGF; MMP; Sampson's theory; angiogenesis; immune dysfunction; retrograde menstruation.

Отримано 5.09.2019 